\title{
Population variability in some genes involving the haemostatic system: data on the general population of Corsica (France), Sardinia and Sicily (Italy)
}

\author{
Alessandra Falchi ${ }^{1,3}$, Lucia Vacca ${ }^{1}$, Antonio Lopez Alomar ${ }^{2}$, Esther Esteban ${ }^{2}$, Marc Memmi ${ }^{3}$, \\ Laurent Varesi ${ }^{3}$, Pedro Moral ${ }^{2}$ and Giuseppe Vona ${ }^{1}$ \\ ${ }^{1}$ Department of Experimental Biology, University of Cagliari, Italy. \\ ${ }^{2}$ Department of Animal Biology, Section of Anthropology, University of Barcelona, Spain. \\ ${ }^{3}$ Faculty of Sciences and Techniques, Corte University, Corte, Corsica, France.
}

\begin{abstract}
Three different population samples from Corsica (France), Sardinia and Sicily (Italy) were studied using nine genetic markers. For the first time, allele distributions of FGA Taql, FGB Bcl I, FGB Hind III, PAI-1 Hind III, PLAT TPA-25, GPIIla Taq I, GPIlb I/D 9bp, FVII HVR4 and FVII -323 10 bp markers, which are thought to be associated with cardiovascular disease risk, were studied in the general population of the three islands. The frequencies of the markers analysed in the present work show some peculiarities: the locus FVII HVR4 is characterized by the presence of a rare allele $(\mathrm{H} 5)$, found in Corsicans and in Sardinians; the locus FBG Bcll shows a low frequency of the B1 allele and the absence of the B1B1 genotype. The frequencies of some alleles have a distribution that is in agreement with the low risk for cardiovascular diseases in south European countries. The results highlight a genetic differentiation between the three Mediterranean islands and the other European populations.
\end{abstract}

Key words: haemostatic genes, genetic markers, Mediterranean populations.

Received: January 20, 2003; Accepted: December 4, 2003.

\section{Introduction}

Genes involved in haemostasis are relevant candidate genes for susceptibility to cardiovascular diseases. During the last decades, a growing number of common polymorphisms in the genes that encode coagulation, as well as fibrinolytic and adhesive platelet proteins, have been associated with coronary heart disease (Reiner et al., 2001). In spite of the great interest in these polymorphisms for epidemiological studies, little is known about their variation in the general population. On the other hand, several previous studies of these genetic markers related to risk and disease resistance have proved useful for the study of human populations (Bernardi et al., 1996; Tishkoff et al., 2000).

We have explored, for the first time, the frequency distributions of the nine markers in seven haemostatic genes of three general population samples from Corsica (France), Sardinia and Sicily (Italy). We studied: alpha and beta fibrinogen (FGA: OMIM 134820, and FGB: OMIM 134830, respectively, at 4q28), factor VII (F7: OMIM 227500, 13q34), plasminogen activator inhibitor-1 (PAI1:

Send correspondence to Giuseppe Vona. University of Cagliari, Section of the Anthropological Sciences, Department of Experimental Biology. S.S. 554 km 4.5, Monserrato, Cagliari, Italy. E-mail: vona@unica.it.
OMIM 173360, 7q21.3-q22), plasminogen activator tissue (PLAT: OMIM 173370, 8p12), and alpha and beta subunits of the platelet GPIIb/IIIa integrin complex (GPIIb or ITGA2B: OMIM 273800, and GpIIIa or ITGB3: OMIM 173470 , respectively, at $17 \mathrm{q} 21.32$ ). Some of these polymorphic sites have been reported as being associated with the risk for cardiovascular disease (de Maat et al., 1995; de Maat et al., 1997; van der Bom et al., 1997; Weiss et al., 1996; Zito et al., 1999; Di Castelnuovo et al., 2000).

The fibrinogen gene cluster contains three of the RFLP markers examined, which include HindIII $\left(\mathrm{C} / \mathrm{T}^{-148}\right.$ base change) at the promoter, the $\mathrm{BclI}$ restriction site in the 3' region of the FGB gene, and RFLP/TaqI in the 3' region of the FGA gene. Allele variants of these markers have shown to be associated with an increased plasma fibrinogen level, which is an independent risk indicator for cardiovascular disease (de Maat et al., 1995; Iso et al., 1995; Zito et al., 1997, Donati et al., 2000). Genetic variation of the Factor VII gene (F7) was tested by means of the Insertion/Deletion (at the -323 site in the promoter region) and the HVR4 (VNTR of $37 \mathrm{bp}$ repeat core next to intron G) markers. The I (Insertion) and H7 (HVR4) alleles have been reported to be associated with low Factor VII plasma concentration, which is interpreted as conferring protection against the risk of cardiovascular disease (Iacoviello et al., 
1998; Girelli et al., 2000; Geng et al., 2003). Moreover, the typed RFLP/HindIII polymorphism in the 3' region of the fibrinolytic protein plasminogen activator inhibitor (PAI1) influences the plasma levels (PAI-1) and has been associated with the development of cardiovascular disease (Benza et al., 1998; Lee et al., 1999). The only exception to the lack of population studies is the Alu insertion polymorphism, located within intron 8 of the PLAT gene, the geographic distribution of which has been extensively studied (Ludwig et al., 1992; Tishkoff et al., 2000). Contrasting results of association studies on thrombosis and myocardial infarction risk suggest that this polymorphism is not a major risk factor in cardiovascular disease (van der Bom et al., 1997; Steeds et al., 1998). Lastly we typed the RFLP/TaqI (A_C base change at the 20500 site in exon 9) of the GPIIIa gene and the Ins/Del (9bp) at intron 21 of the GpIIb gene (Zimrin et al., 1990; Peyruchaud et al., 1995). The proteins encoded by these genes influence the interaction of the platelet vessel walls or thrombus formation and therefore they may also be candidate genes for coronary heart disease risk.

This paper analyses the distribution of the previously mentioned markers in three autochthonous population samples from Corsica, Sardinia and Sicily. Our main purpose was to determine the degree of population variability of these candidate genes for CAD (coronary artery disease) in a set of geographically related populations who present certain genetic peculiarities (Ghiani et al., 2002; Varesi et al., 2000; Vona, 1997; Vona et al., 2001). These may include aspects such as degrees of isolation and different incidences of malaria epidemics from other Mediterranean regions, as well as lower cardiovascular prevalences, as compared to north and central Europe (Iacoviello et al., 1998).

\section{Material and Methods}

Blood samples were obtained from 292 apparently healthy, unrelated blood bank donors (157 males and 135 females). The donors, as well as their parents and grandparents, were born and residing in some areas of Corsica $(\mathrm{N}=92)$ (France), Sardinia $(\mathrm{N}=100)$ and Sicily $(\mathrm{N}=100)$ (Italy). All individuals were aged between 25 and 65 years $(\mathrm{x}=46.9 \pm 0.25)$ and gave their informed agreement to be included in this research. DNA was extracted from the blood samples by the phenol-chloroform method. The samples were then amplified with oligonucleotides, under conditions previously described by the authors listed in Table 1.

Allele frequencies were determined by gene counting. Genotype frequencies were tested to see if they were in agreement with the Hardy-Weinberg equilibrium expectations, using Fisher's Exact Test (Guo and Thompson, 1992) helped by the statistical software package Arlequin (Schneider et al., 2000). The Bonferroni correction was applied (Weir, 1991), and unbiased estimates of expected heterozygosity were computed as proposed by Nei (1978). Fisher's Exact Test was used to calculate heterogeneity for single markers and for the overall total of seven markers in our three samples. Genetic distances were calculated according to Nei's method (Nei, 1972), and a neighbor-joining tree (Saitou and Nei, 1987) was constructed from the matrix of genetic distances using the PHYLIP 3.5 package (Felsenstein, 1993). The tree topology was assessed through 1000 bootstrap iterations.

\section{Results}

Genotype and allele frequencies for the nine polymorphisms studied in the Corsican (France), Sardinian and

Table 1 - Chromosomal localizations, oligonucleotides and type of the studied genetic markers.

\begin{tabular}{|c|c|c|c|c|}
\hline Markers & Localiz. & Primer & Type & Reference \\
\hline FGA TaqI & $4 q 28$ & $\begin{array}{l}\text { 5'-AGCCGTGCCTATCTTTG-3' } \\
\text { 5'-TGTCTCAGGTACATTTAGC-3' }\end{array}$ & RFLP & Thomas et al., 1994 \\
\hline FGB Bcl I & $4 q 28$ & $\begin{array}{l}\text { 5'-ACCTGGTTTTCTTGCCACAAG-3', } \\
\text { 5'-AATAGTTCTCATACCACAGTGT-3' }\end{array}$ & RFLP & Thomas et al., 1994 \\
\hline FGB Hind III & $4 q 28$ & $\begin{array}{l}\text { 5'-TGGTTGCCTTGTGAGTAGG-3' } \\
\text { 5'-ATTGTCGTTGACACCTTGGG-3' }\end{array}$ & RFLP & GenBank (M64983) \\
\hline PAI-1 Hind III & $7 \mathrm{q} 21.3-22$ & $\begin{array}{l}\text { 5'-AGCAATCCACCTGTCTCGGC-3' } \\
\text { 5'-TCCTGACCTCAGGTGATCCG-3' }\end{array}$ & RFLP & Grenett et al., 2000 \\
\hline PLAT TPA-25 & $8 \mathrm{p} 12-\mathrm{q} 11.2$ & $\begin{array}{l}\text { 5'-GTGAAAAGCAAGGTCTACCAG-3' } \\
\text { 5'-GACACCGAGTTCATCTTGAC-3' }\end{array}$ & Ins.Alu & Tishkoff et al., 1996 \\
\hline FVII HVR4 & $13 q 34$ & $\begin{array}{l}\text { 5'-AATGTGACTTCCACACCTCC-3' } \\
\text { 5'-GATGTCTGTCTGTCTGTGGA-3' }\end{array}$ & VNTR & Marchetti et al., 1991 \\
\hline FVII -323 10bp & $13 q 34$ & $\begin{array}{l}\text { 5'-AGGCTCTCTTCAAATAATTACATC-3' } \\
\text { 5'-CGGGCTGGCTCCTGGATTT-3' }\end{array}$ & $\mathrm{I} / \mathrm{D}$ & Marchetti et al., 1993 \\
\hline GPIIIa Taq I & $17 \mathrm{q} 21.32$ & $\begin{array}{l}\text { 5'-TTTCTTGTCTTCTTGTGCCC-3' } \\
\text { 5'-TGTCTCCAATCTTGAGTCCC-3' }\end{array}$ & RFLP & GenBank (M32674) \\
\hline GPIIb 9bp & $17 \mathrm{q} 21.32$ & $\begin{array}{l}\text { 5'-CAGACCTTCCAAGGGAGCTT-3', } \\
\text { 5'-GTGAGGACCAAGATTCTGGC-3' }\end{array}$ & $\mathrm{I} / \mathrm{D}$ & Peyruchaud et al., 1995 \\
\hline
\end{tabular}


Sicilian (Italy) populations are reported in Tables 2 and 3, respectively; values of $\mathrm{p}$ for the Hardy-Weinberg equilibrium, the observed $\left(\mathrm{H}^{\circ}\right)$ and the expected $\left(\mathrm{H}^{\mathrm{e}}\right)$ heterozygosity are also shown in these tables. The genotype distributions were found in general accordance with the Hardy-Weinberg equilibrium expectations, with the exceptions of PAI-1 Hind III and PLAT TPA-25 in Corsicans, and PLAT TPA-25, FVII HVR4 and GPIIIa TaqI in Sardinians. The significant departure from the Hardy-Weinberg equilibrium found for PLAT TPA-25 in the Corsican sample was due to a great reduction of the heterozygote frequencies. On the other hand, a significant excess of heterozygotes was observed in the Corsican sample for the PAI-1 HindIII marker, and for the PLAT TPA-25 and GPIIIa TaqI loci in the Sardinian sample. As for the FVII
HVR4 marker in the Sardinian sample, the divergence was due to the presence of a rare $\mathrm{H} 5-\mathrm{H} 5$ homozygote. Using the Bonferroni correction for multiple comparisons, however, the significance of these values disappears.

The expected heterozygosity levels ranged from a minimum of 0.188 in FGB BclI in the Sardinian sample to a maximum of 0.503 for the FVII HVR4 locus in the Sicilians (Table 3 ). The overall mean heterozygosity values for the nine loci for the Corsican, Sardinian and Sicilian samples were $0.338,0.363$ and 0.402 , respectively.

Fisher's Exact Test among the three populations and for all the markers examined showed a significant genetic differentiation value $\left(\chi^{2}=137.4\right.$; d.f $\left.=54 ; \mathrm{p}<0.0001\right)$. The values of this test for the genetic differentiation by locus showed that the three populations were heterogeneous with

Table 2 - Genotype frequencies and probability of test for the Hardy Weinberg equilibrium at nine loci in the three Mediterranean populations.

\begin{tabular}{|c|c|c|c|c|c|c|c|}
\hline \multicolumn{4}{|l|}{ FGA TaqI } & \multicolumn{4}{|l|}{ GPIIIa Taq I } \\
\hline Genotype freq. & Corsica & Sardinia & Sicily & Genotype freq. & Corsica & Sardinia & Sicily \\
\hline $\mathrm{T} 1 / \mathrm{T} 1$ & $14(15.7)$ & $4(4.1)$ & $8(8)$ & $\mathrm{T} 1 / \mathrm{T} 1$ & 0 & 0 & $6(6)$ \\
\hline $\mathrm{T} 1 / \mathrm{T} 2$ & $28(30)$ & $26(26.3)$ & $44(44)$ & $\mathrm{T} 1 / \mathrm{T} 2$ & $32(34.8)$ & $54(54.5)$ & $28(28)$ \\
\hline $\mathrm{T} 2 / \mathrm{T} 2$ & $50(54.3)$ & $69(69.6)$ & $48(48)$ & $\mathrm{T} 2 / \mathrm{T} 2$ & $60(65.2)$ & $45(45.5)$ & $66(66)$ \\
\hline $\mathrm{HW}(\mathrm{p})$ & 0.077 & 0.476 & 1 & $\mathrm{HW}(\mathrm{p})$ & 0.317 & 0.0001 & 0.379 \\
\hline \multicolumn{4}{|l|}{ FGB Bcl I } & \multicolumn{4}{|l|}{ GPIIb I/D } \\
\hline Genotype freq. & Corsica & Sardinia & Sicily & Genotype freq. & Corsica & Sardinia & Sicily \\
\hline B1/B1 & 0 & 0 & 0 & $\mathrm{I} / \mathrm{I}$ & $30(32.6)$ & $53(53)$ & $34(34)$ \\
\hline $\mathrm{B} 1 / \mathrm{B} 2$ & $24(26)$ & $19(20.8)$ & $24(24)$ & $\mathrm{I} / \mathrm{D}$ & $50(54.4)$ & $44(44)$ & $50(50)$ \\
\hline $\mathrm{B} 2 / \mathrm{B} 2$ & $68(74)$ & $72(79.2)$ & $76(76)$ & $\mathrm{D} / \mathrm{D}$ & $12(13)$ & $3(3)$ & $16(16)$ \\
\hline HW (p) & 1 & 0.589 & 1 & HW (p) & 0.54 & 0.119 & 1 \\
\hline \multicolumn{4}{|l|}{ FGB Hind III } & \multicolumn{4}{|l|}{ FVII -323 10bp } \\
\hline Genotype freq. & Corsica & Sardinia & Sicily & Genotype freq. & Corsica & Sardinia & Sicily \\
\hline Hd1/Hd1 & $70(76)$ & $59(59)$ & $66(66)$ & $\mathrm{I} / \mathrm{I}$ & $4(4.3)$ & $5(5)$ & $10(10)$ \\
\hline $\mathrm{Hd} 1 / \mathrm{Hd} 2$ & $22(24)$ & $36(36)$ & $28(28)$ & $\mathrm{I} / \mathrm{D}$ & $44(47.8)$ & $35(35.4)$ & $24(24)$ \\
\hline $\mathrm{Hd} 2 / \mathrm{Hd} 2$ & 0 & $5(5)$ & $6(6)$ & $\mathrm{D} / \mathrm{D}$ & $44(47.9)$ & $59(59.6)$ & $66(66)$ \\
\hline $\mathrm{HW}(\mathrm{p})$ & 1 & 1 & 0.379 & $\mathrm{HW}(\mathrm{p})$ & 0.299 & 0.787 & 0.041 \\
\hline \multicolumn{4}{|l|}{ PAI-1 Hind III } & \multicolumn{4}{|l|}{ FVII -HVR4 } \\
\hline Genotype freq. & Corsica & Sardinia & Sicily & Genotype freq. & Corsica & Sardinia & Sicily \\
\hline $\mathrm{Hd} 1 / \mathrm{Hd} 1$ & $2(2.1)$ & $30(30.3)$ & $26(26)$ & H5/H5 & 0 & $1(1.03)$ & 0 \\
\hline $\mathrm{Hd} 1 / \mathrm{Hd} 2$ & $72(78.2)$ & $49(49.5)$ & $62(62)$ & H5/H6 & $2(2.17)$ & 0 & 0 \\
\hline $\mathrm{Hd} 2 / \mathrm{Hd} 2$ & $18(19.7)$ & $20(20.2)$ & $12(12)$ & H6/H6 & $50(54.33)$ & $58(59.8)$ & $30(30)$ \\
\hline \multirow[t]{2}{*}{ HW (p) } & 0.001 & 1 & 0.088 & H7/H6 & $32(34.8)$ & $30(30.9)$ & $46(46)$ \\
\hline & & & & $\mathrm{H} 7 / \mathrm{H} 7$ & $8(8.7)$ & $8(8.25)$ & $24(24)$ \\
\hline PLAT TPA-25 & & & & $\mathrm{HW}(\mathrm{p})$ & 0.779 & 0.001 & 0.579 \\
\hline Genotype freq. & Corsica & Sardinia & Sicily & & & & \\
\hline $\mathrm{I} / \mathrm{I}$ & $26(28.3)$ & $3(3)$ & $24(24)$ & & & & \\
\hline $\mathrm{I} / \mathrm{D}$ & $32(34.8)$ & $80(80)$ & $44(44)$ & & & & \\
\hline $\mathrm{D} / \mathrm{D}$ & $34(36.9)$ & $17(17)$ & $32(32)$ & & & & \\
\hline HW (p) & 0.042 & 0.001 & 0.406 & & & & \\
\hline
\end{tabular}


Table 3 - The allele frequencies of the haemostasis markers, heterozygosity values and p values of genic differentiation in the Corsican, Sardinian and Sicilian populations $(\mathrm{SE}=$ Standard Error, Ho = observed Heterozygosity and He $=$ Heterozygosity Nei 1978, $\mathrm{p}=$ values of genic differentiation between populations for locus).

\begin{tabular}{|c|c|c|c|c|c|c|c|c|c|c|c|c|c|}
\hline \multicolumn{7}{|l|}{ FGA TaqI } & \multicolumn{7}{|l|}{ GPIIIa Taq I } \\
\hline Allele freq. & Corsica & $\mathrm{SE}^{\mathrm{a}}$ & Sardinia & $\mathrm{SE}$ & Sicily & $\mathrm{SE}$ & Allele freq. & Corsica & $\mathrm{SE}$ & Sardinia & $\mathrm{SE}$ & Sicily & $\mathrm{SE}$ \\
\hline $\mathrm{T} 2$ & 0.695 & \pm 0.053 & 0.828 & \pm 0.028 & 0.700 & \pm 0.050 & $\mathrm{~T} 2$ & 0.826 & \pm 0.042 & 0.727 & \pm 0.034 & 0.8 & \pm 0.042 \\
\hline $\mathrm{H}^{\mathrm{o}}$ & 0.300 & & 0.263 & & 0.440 & & $\mathrm{H}^{\mathrm{o}}$ & 0.348 & & 0.545 & & 0.280 & \\
\hline $\mathrm{H}^{\mathrm{e}}$ & 0.428 & & 0.286 & & 0.424 & & $\mathrm{H}^{\mathrm{e}}$ & 0.290 & & 0.399 & & 0.323 & \\
\hline \multicolumn{7}{|l|}{$\mathrm{p}=0.01$} & \multicolumn{7}{|l|}{$\mathrm{p}=0.12$} \\
\hline \multicolumn{7}{|l|}{ FGB Bcl I } & \multicolumn{7}{|l|}{ GPIIb I/D } \\
\hline Allele freq. & Corsica & SE & Sardinia & $\mathrm{SE}$ & Sicily & $\mathrm{SE}$ & Allele freq. & Corsica & $\mathrm{SE}$ & Sardinia & $\mathrm{SE}$ & Sicily & $\mathrm{SE}$ \\
\hline B2 & 0.869 & \pm 0.036 & 0.896 & \pm 0.023 & 0.880 & \pm 0.034 & I & 0.598 & \pm 0.059 & 0.750 & \pm 0.033 & 0.590 & \pm 0.057 \\
\hline $\mathrm{H}^{\mathrm{o}}$ & 0.260 & & 0.208 & & 0.240 & & $\mathrm{H}^{\mathrm{o}}$ & 0.544 & & 0.440 & & 0.500 & \\
\hline $\mathrm{H}^{\mathrm{e}}$ & 0.230 & & 0.188 & & 0.213 & & $\mathrm{H}^{\mathrm{e}}$ & 0.486 & & 0.377 & & 0.489 & \\
\hline \multicolumn{7}{|l|}{$\mathrm{p}=0.74$} & \multicolumn{7}{|l|}{$\mathrm{p}=0.00$} \\
\hline \multicolumn{7}{|c|}{ FGB Hind III } & \multicolumn{7}{|l|}{ FVII -323 10bp } \\
\hline Allele freq. & Corsica & SE & Sardinia & SE & Sicily & SE & Allele freq. & Corsica & SE & Sardinia & SE & Sicily & SE \\
\hline Hd1 & 0.880 & \pm 0.035 & 0.770 & \pm 0.032 & 0.800 & \pm 0.042 & $\mathrm{D}$ & 0.717 & \pm 0.051 & 0.773 & \pm 0.032 & 0.780 & \pm 0.044 \\
\hline $\mathrm{H}^{\mathrm{o}}$ & 0.240 & & 0.360 & & 0.280 & & $\mathrm{H}^{\mathrm{o}}$ & 0.478 & & 0.354 & & 0.240 & \\
\hline $\mathrm{H}^{\mathrm{e}}$ & 0.213 & & 0.356 & & 0.323 & & $\mathrm{H}^{\mathrm{e}}$ & 0.410 & & 0.353 & & 0.347 & \\
\hline \multicolumn{7}{|l|}{$\mathrm{p}=0.08$} & \multicolumn{7}{|l|}{$\mathrm{p}=0.50$} \\
\hline \multicolumn{7}{|c|}{ PAI-1 Hind III } & \multicolumn{7}{|l|}{ FVII-HVR4 } \\
\hline Allele freq. & Corsica & SE & Sardinia & SE & Sicily & SE & Allele freq. & Corsica & SE & Sardinia & SE & Sicily & $\mathrm{SE}$ \\
\hline $\mathrm{Hd} 2$ & 0.587 & \pm 0.067 & 0.449 & \pm 0.042 & 0.430 & \pm 0.058 & H5 & 0.011 & \pm 0.074 & 0.010 & \pm 0.050 & 0.000 & \pm 0.070 \\
\hline $\mathrm{H}^{\mathrm{o}}$ & 0.782 & & 0.495 & & 0.620 & & H6 & 0.728 & \pm 0.050 & 0.753 & \pm 0.033 & 0.530 & \pm 0.060 \\
\hline $\mathrm{H}^{\mathrm{e}}$ & 0.490 & & 0.497 & & 0.495 & & $\mathrm{H} 7$ & 0.261 & \pm 0.071 & 0.237 & \pm 0.049 & 0.470 & \pm 0.062 \\
\hline \multicolumn{7}{|l|}{$\mathrm{p}=0.05$} & $\mathrm{H}^{\mathrm{o}}$ & 0.370 & & 0.310 & & 0.460 & \\
\hline \multicolumn{7}{|c|}{ PLAT TPA-25 } & $\mathrm{H}^{\mathrm{e}}$ & 0.406 & & 0.379 & & 0.503 & \\
\hline Allele freq. & Corsica & SE & Sardinia & $\mathrm{SE}$ & Sicily & SE & $\mathrm{p}=0.00$ & & & & & & \\
\hline $\mathrm{D}$ & 0.543 & \pm 0.062 & 0.570 & \pm 0.041 & 0.540 & \pm 0.059 & & & & & & & \\
\hline $\mathrm{H}^{\mathrm{o}}$ & 0.348 & & 0.800 & & 0.440 & & & & & & & & \\
\hline $\mathrm{H}^{\mathrm{e}}$ & 0.502 & & 0.493 & & 0.502 & & & & & & & & \\
\hline $\mathrm{p}=0.84$ & & & & & & & & & & & & & \\
\hline
\end{tabular}

respect to FGA TaqI, PAI-1 HindIII, GpIIb 9 bp I/D and FVII HVR4. FVII HVR4 showed the highest variability, whereas TPA-25 showed the lowest variability, as compared to the other loci.

There are few available data in the related literature on the general European population and therefore only some comparisons among frequencies could be made (Table 4). For FGA Taq I, the frequency in the Sardinian sample was similar to those of other European populations, whose T2 allele frequencies range from 0.710 (Netherlands) to 0.849 (Basque Country), while those of the Corsican and Sicilian populations were lower.

Only the Italian samples showed a lower frequency (0.720) for the B2 allele of FGB Bcl I, the three Mediterra- nean islands presenting frequencies similar to all the other populations listed in Table 4. The Corsican sample showed a higher (0.880) frequency for the Hd1 allele of the FGB HindIII locus, while the allele frequencies of the Sardinian and Sicilian samples were similar to those of the other populations. Regarding the PAI-1 HindIII locus, the allele frequencies of our samples were within the range of the populations listed in Table 4. The Corsican and Sicilian samples showed the higher frequencies for the allele T2 of the GpIIIa locus and lower frequencies for the allele I of the GpIIb locus, respectively. The FVII -323 10bp deletion showed a lower frequency on the three islands than in any other European population. Notably, the high frequency found for the $\mathrm{H} 7$ allele of the FVII HVR4 polymorphism in 
the Sicilian sample occurred simultaneously with the absence of H5. Our three Mediterranean populations were found to have high frequencies for the PLAT TPA-25 locus, as compared to the other European populations (Table 4).

The neighbour-joining tree shown in Fig. 1 is based on genetic distances computed according to Nei (1972), using the gene frequencies of 6 loci (FGA TaqI, FGB HindIII, FGB BclI, FVII -323 10bp, FVII HVR4, and PLAT TPA25) from Tables 1 and 4 . The gene frequencies of European populations were pooled in two samples: North Europeans (Denmark, England, Ireland, the Netherlands, Norway and Sweden) and Central-South Europeans (Austria, Basque Country, France, Italy and Central Spain). The tree clearly shows a great genetic differentiation among the studied populations, with strong bootstrap support.

\section{Discussion}

We investigated the frequencies of nine DNA genetic markers and, since their variation is not well known, we studied them in the general population of three west Mediterranean islands: Corsica (France), Sardinia and Sicily (Italy). The frequencies obtained showed some peculiarities: 1) $\mathrm{T} 2$ (FGA TaqI) and I (GPIIb I/D) were remarkably higher in Sardinians than in Sicilians or Corsicans; 2)
Corsicans were characterised by a higher frequency of $\mathrm{Hd} 1$ (FGB HindIII) and Hd2 (PAI-1 HindIII); 3) Corsicans and Sardinians presented a rare allele (H5) in the FVII HVR4 marker; 4) The three islands were characterised by a low frequency of the allele B1 and total absence of the genotype B1B1 (FGB BclI). This allele variant has shown to be associated with an increased plasma fibrinogen level, which is an independent risk indicator for cardiovascular disease (de Maat et al., 1995; Iso et al., 1995; Zito et al., 1997; Donati et al., 2000).

The global heterogeneity found among the three island populations proved to be very significant. The genetic tree indicated a certain degree of differentiation among the compared populations. The results obtained using classical genetic markers (Vona, 1997; Memmì et al., 1998; Ghiani et al., 2002) and sequences of mtDNA indicated a sharp differentiation between Corsicans and Sardinians with respect to Sicilians (Vona et al., 2001) and the other Mediterranean populations (Vona et al., 2003, Falchi et al., 2003). The genetic differentiation between Corsicans and Sardinians appeared to be lower than the one among the other European populations. This might be explained by the reciprocal exchange that has taken place between the two populations ever since prehistoric times. For instance, during the late Neolithic period, north Sardinia saw the «Megalithic Circle» culture, that was in strong correspondence with the

Table 4 - Allele frequencies in different ethnic groups.

\begin{tabular}{|c|c|c|c|c|c|c|c|c|c|c|c|c|c|}
\hline & FGA Taq I & FGB Bcl I & FGB & PAI-1 & GPIIIa & GPIIb & FVII -323 & \multicolumn{4}{|c|}{ FVII-HVR4 } & PLAT & References \\
\hline Population & $\mathrm{T} 2$ & B2 & Hd1 & $\mathrm{Hd} 2$ & $\mathrm{~T} 2$ & I & D & H5 & H6 & $\mathrm{H} 7$ & H8 & D & \\
\hline Corsica & 0.695 & 0.869 & 0.880 & 0.587 & 0.826 & 0.598 & 0.717 & 0.011 & 0.728 & 0.261 & 0.000 & 0.544 & Present study \\
\hline Sardinia & 0.828 & 0.896 & 0.770 & 0.449 & 0.727 & 0.750 & 0.773 & 0.010 & 0.753 & 0.237 & 0.000 & 0.570 & Present study \\
\hline Sicily & 0.700 & 0.880 & 0.800 & 0.430 & 0.800 & 0.590 & 0.780 & 0.000 & 0.530 & 0.470 & 0.000 & 0.540 & Present study \\
\hline Italy & & 0.720 & & & & & 0.873 & 0.007 & 0.638 & 0.356 & 0.000 & & $\begin{array}{l}\text { Zito et al., 1997; } \\
\text { Dell'Acqua et.al., 1997; } \\
\text { Iacoviello et al., } 1998\end{array}$ \\
\hline North Italy & & & & & & & & 0.019 & 0.658 & 0.323 & 0.000 & & Girelli et al., 2000 \\
\hline $\begin{array}{l}\text { Italy (North, } \\
\text { Center, South) }\end{array}$ & & & & & & & 0.835 & 0.010 & 0.679 & 0.320 & 0.000 & & $\begin{array}{l}\text { Di Castelnuovo et } \\
\text { al., } 2000\end{array}$ \\
\hline Austria & & & 0.752 & & & & & & & & & & Schmidt et al., 1998 \\
\hline Central Spain & 0.790 & 0.837 & 0.780 & 0.404 & 0.740 & 0.700 & 0.840 & 0.010 & 0.720 & 0.270 & 0.000 & 0.411 & $\begin{array}{l}\text { Comas et al., 2000; } \\
\text { Batalla et al., 2001; } \\
\text { Lopez Alomar }\end{array}$ \\
\hline Basques & 0.849 & 0.841 & 0.806 & 0.346 & 0.718 & 0.560 & 0.972 & 0.000 & 0.632 & 0.368 & 0.000 & 0.412 & Lopez Alomar \\
\hline France & 0.764 & 0.829 & & & & 0.700 & & & & & & 0.275 & $\begin{array}{l}\text { Behague } \text { et al., 1996; } \\
\text { Peyruchaud } \text { et al., 1995; } \\
\text { Ruan et al., } 1993\end{array}$ \\
\hline England & 0.730 & 0.850 & 0.810 & & & & 0.883 & 0.046 & 0.672 & 0.282 & 0.000 & & $\begin{array}{l}\text { Thomas et al., 1994; } \\
\text { Humphries et al., 1996; } \\
\text { de Knijff et al., } 1994\end{array}$ \\
\hline Netherland & 0.710 & 0.830 & & & & & 0.861 & & & & & & $\begin{array}{l}\text { de Maat et al., 1997; de } \\
\text { Knijff } \text { et al., 1994; } \\
\text { Doggen } \text { et al., } 2000\end{array}$ \\
\hline Sweden & & & & 0.463 & & & & & & & & & Dawson et al., 1991 \\
\hline Ireland & & & & 0.632 & & & & & & & & & Lee et al., 1999 \\
\hline Norway & 0.734 & 0.826 & & & & & & & & & & & Berg and Kierulf \\
\hline Denmark & & & & & & & & 0.024 & 0.690 & 0.274 & 0.012 & 0.500 & $\begin{array}{l}\text { de Knijff et al., 1994; } \\
\text { Tishkoff et al., } 2000\end{array}$ \\
\hline $\begin{array}{l}\text { Northen } \\
\text { Europe }\end{array}$ & 0.732 & 0.838 & 0.810 & 0.548 & & & 0.872 & 0.035 & 0.681 & 0.278 & 0.006 & 0.447 & pooled data \\
\hline $\begin{array}{l}\text { Southern } \\
\text { Europe }\end{array}$ & 0.764 & 0.775 & 0.820 & 0.375 & 0.729 & 0.653 & 0.854 & 0.011 & 0.670 & 0.317 & & 0.343 & pooled data \\
\hline
\end{tabular}




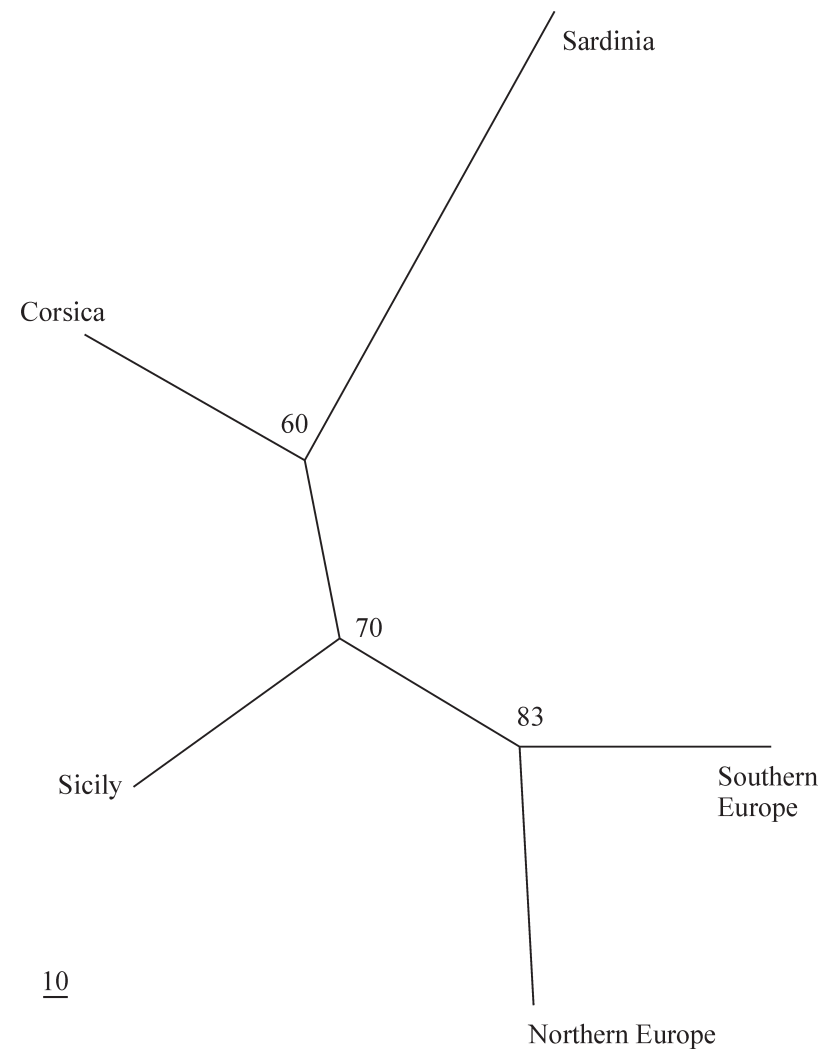

Figure 1 - Neighbour-joinig tree for 6 of the 9 loci analysed in the studied populations.

contemporaneous «Torreana» culture in Corsica. The contact between the two islands continued throughout both the Bronze and Iron Ages. The relationship between Corsica and southern Sardinia is also obvious in their dialectal origins (Blasco-Ferrer, 1984; Lilliu, 1988). The classical genetic markers and mtDNA (Varesi et al., 2000; Vona et al., 2002; Vona et al., 2003) confirm the hypothesis of a common origin shared by the two populations and lead to the conclusion that Corsicans and Sardinians are genetically similar, although not identical. Demographic events may have contributed to this differentiation, triggering a series of phenomena which produced the effects of genetic drift. It is sufficient to recall: 1) the low population density and the serious epidemics which caused bottleneck effects; 2) the long periods of internal and external isolation experienced by many Corsican and Sardinian villages (Vona, 1997). The analysis of the genetic structure of Sicily has been pursued by several authors using different sets of genetic markers, mtDNA (Piazza et al., 1988; Rickards et al., 1998; Vona et al., 2001), and names and surnames (Guglielmino et al., 1991; Zei et al., 1993). Their results show that the Sicilian gene pool has been influenced by other Mediterranean populations because of the various immigrations which took place in Sicily (Vona et al., 2001). Both the analyses made previously by several authors and our present results indicate that genetically Sicily occupies a mid- way position between Corsica and Sardinia and other European populations.

Several works highlighted the fact that some of the genes analysed in the present study seem to show a correlation with cardiovascular diseases. In our research, we have found that the frequency distribution of the allele B1 of the locus FGB BclI, of the allele T1 of the locus FGA TaqI and of the allele I of the FVII -323 10bp in Sardinia, and the frequency distribution of the allele H7 (FVII HVR4) in Sicily are in agreement with the low risk for cardiovascular diseases of the south European countries (Iacoviello et al., 1998). Furthermore, the population heterogeneity could be extremely interesting to clarify the distribution process of cardiovascular diseases, as there is such a diversity of patterns of different pathologies between the other European and Mediterranean populations (Tunstall-Pedoe et al., 1994).

\section{Acknowledgments}

This research was funded by the MURST grant, ex 40\%, 2000 (V.G.); the Italy-Spain Cooperation Programme, 2001 (V.G. and M.P.), the Spanish Research Dept. Unit, 2000 (M.P.) and the programme INTERREG III (V.G. and V.L.).

\section{References}

Batalla A, Alvarez R, Reguero, Gonzalez P, Alvarez V, Cubero GI, Cortina A and Coto E (2001) Lack of association between polymorphisms of the coagulation factor VII and myocardial infarction in middle-age Spanish men. Int $\mathrm{J}$ Cardiol 80:209-212.

Behague I, Poirier O, Nicaud V, Evans A, Arveiler D, Luc G, Cambou JP, Scarabin PY, Bara L, Green F and Cambien F (1996) Beta fibrinogen gene polymorphisms are associated with plasma fibrinogen and coronary artery disease in patients with myocardial infarction. The ECTIM Study. Etude Cas-Temoins sur l'Infarctus du Myocarde. Circulation 93:440-9

Benza RL, Grenett HE, Bourge RC, Kirklin JK, Naftel DC, Castro PF, McGiffin DC, George JF and Booyse FM (1998) Gene polymorphisms for plasminogen activator inhibitor-1/tissue plasminogen activator and development of allograft coronary artery disease. Circulation 98:2248-2254.

Berg K and Kierulf P (1999) DNA polymorphisms at fibrinogen loci and plasma fibrinogen concentration. Clin Genet 36:229-235.

Bernardi F, Marchetti G, Pinotti M, Arcieri P, Baroncini C, Papacchini M, Zepponi E, Ursicino N, Chiarotti F and Mariani G (1996) Factor VII gene polymorphisms contribute about one third of the factor FVII level variation in plasma. Arterioscler Thromb Vasc Biol 16:72-6.

Blasco-Ferrer E (1984) Storia linguistica della Sardegna, Tubingen, Max Niemeyer.

Comas D, Calafell F, Benchemsi N, Helal A, Lefranc G, Stoneking M, Batzer MA, Bertranpetit J and Sajantila A (2000) Alu insertion polymorphisms in NW Africa and the 
Iberian Peninsula: evidence for a strong genetic boundary through the Gibraltar Straits. Hum Genet 107(4):312-9.

Dawson S, Hamsten A, Wiman B, Henney A and Humphries S (1991) Genetic variation at the plasminogen activator inhibitor-1 locus is associated with altered levels of plasma plasminogen activator inhibitor-1 activity. Arterioscler Thromb 11:183-190.

de Knijff P, Green F, Johansen LG, Grootendorst D, Temple A, Cruickshank JK, Humphries SE, Jespersen J and Kluft C (1994) New alleles in F7 VNTR. Hum Mol Genet 3:384.

de Maat MPM, de Knijff P, Green FR, Thomas AE, Jespersen J and Kluft C (1995) Gender related association between $\beta$-fibrinogen genotype and plasma fibrinogen levels and linkage disequilibrium at the fibrinogen locus in Greenland Inuit. Arterioscler Thromb Vasc Biol 15:856-860.

de Maat MPM, Green F, de Knijff P, Jespersen J and Kluft C (1997) Factor VII polymorphisms in populations with different risks of cardiovascular disease. Arterioscler Thromb Vasc Biol 17(10):1918-1923.

Dell'Acqua G, Iacoviello L, D’Orazio A, Di Bitondo R, Di Castelnuovo A and Donati MB (1997) A polymorphic cluster in the 5' region of the human coagulation factor VII gene: detection, frequency, and linkage disequilibrium. Thromb Res $88: 445-448$

Di Castelnuovo A, D’Orazio A, Amore C, Falanga A, Donati MB and Iacoviello L (2000) The deanucleotide insertion/deletion polymorphism in the promoter region of the coagulation factor VII gene and the risk of familial myocardial infarction. Thromb Res 98(1):9-17.

Doggen CJ, Bertina RM, Cats VM and Rosendaal FR (2000) Fibrinogen polymorphisms are not associated with the risk of myocardial infarction. Br J Haematol 110:935-938.

Donati MB, Zito F, Castelnuovo AD and Iacoviello L (2000) Genes, coagulation and cardiovascular risk. J Hum Hypertens 14 (6):369-372.

Falchi A, Calò C, Piras I, Gonzalez-Perez E, Varesi L, Moral P and Vona G (2003). Alu X chromosome distribution in Mediterranean populations. 15-18 Septiembre XIII SEAB congress, Oviedo (Spain) (in press).

Felsenstein J (1993) PHYLIP (Phylogeny Inference Package) version $3.5 \mathrm{c}$. Distributed by the author. Department of Genetics, University of Washington, Seattle.

Genbank: http://www.ncbi.nlm.nih.gov.

Geng X, Jin GD, Fu GS, Ji MA, Shan J and Wang JA (2003) Polymorphisms in the genes for coagulation factor II, V, VII in patients undergoing coronary angiography. J Zhejiang Univ Sci. 4(3):369-73.

Ghiani ME, Calò MC, Autuori L, Mameli GE, Succa V, Vacca L, Cerutti N, Rabino Massa E and Vona G (2002) Data on the genetic structure of the population of Sicily: Analysis of the Alia population (Palermo, Italy). Am J Human Biol 14: 289-299.

Girelli D, Russo C, Ferraresi P, Olivieri O, Pinotti M, Friso S, Manzato F, Mazzucco A, Berbardi F and Corrocher R (2000) Polymorphisms in the factor VII gene and the risk of myocardial infarction in patients with coronary artery disease. N Engl J Med. 343(11):774-80.

Grenett HE, Khan N, Jiang W and Booyse FM (2000) Identification of the Hind III polymorphic site in the PAI-1 gene: Analysis of the PAI-1 Hind III polymorphism by PCR. Genet Test 4:65-68.
Guglielmino CR, Zei G and Cavalli-Sforza LL (1991) Genetic and cultural transmission in Sicily as revealed by names and surnames. Hum Biol 63:607-627.

Guo SW and Thompson EA (1992) Performing the exact test of Hardy-Weinberg proportion for multiple alleles. Biometrics 48:359.

Humphries S, Temple A, Lane A, Green F, Cooper J and Miller G (1996) Low plasma levels of factor VIIc and antigen are more strongly associated with the 10 base pair promoter (-323) insertion than the glutamine 353 variant. Thromb Haemost 75:567-572.

Iacoviello L, Zito F, Di Castelnuovo A, De Maat M, Kluft C and Donati MB (1998) Contribution of FVII, fibrinogen and fibrinolytic components to the risk of ischaemic cardiovascular disease: Their genetic determinants. Fibrinolysis and Proteolysis 12:259-276.

Iso $\mathrm{H}$, Folsom AR, Winkelmann JC, Koike K, Harada S, Greenberg B, Sato S, Shimamoto T, Iida M and Komachi Y (1995) Polymorphism of the beta fibrinogen gene and plasma fibrinogen concentration in Caucasian and Japanese population samples. Thromb Haemost 73:106-111.

Lee AJ, Fowkes FG, Lowe GD, Connor JM and Rumley A (1999) Fibrinogen, factor VII and PAI-1 genotypes and the risk of coronary and peripheral atherosclerosis: Edinburgh artery study. Thromb Haemost 81:553-560.

Lilliu G (1988) Storia dei Sardi e della Sardegna. v I, Jaka Book, Milano.

Lopez Alomar A (2002) Polimorfismes en gens de l'hemostasi: Estudi poblacional en la mediterranea occidental i associò $\mathrm{amb}$ risc per a la cardiopatia isquemica. $\mathrm{PhD}$ Thesis, Universitat de Barcelona, Spain.

Ludwig M, Wohn KD, Schleuning WD and Oleg K (1992) Allelic dimorphism in the human tissue-plasminogen activator (TPA) gene result of an Alu insertion/deletion event. Hum Genet 88:388-392.

Marchetti G, Gemmati D, Patracchini P, Pinotti M and Bernardi F (1991) PCR detection of a repeat polymorphism within the F7 gene. Nucleic Acids Res 19:4570.

Marchetti G, Patracchini P, Papacchini M, Ferrati M and Bernardi $\mathrm{F}$ (1993) A polymorphism in the 5 region of coagulation factor VII gene (F7) caused by an inserted decanucleotide. Hum Genet 90:575-576.

Memmi M, Moral P, Calò CM, Autuori L, Mameli GE, Succa V, Varesi L and Vona G (1998) Genetic structure of Southwestern Corsica (France). Am J Human Biol 10:567-577.

Nei M (1972) Genetic distances between populations. Amer Nature 106:283-292.

Nei M (1978) Estimation of average heterozygosity and genetic distance from a small number of individuals. Genetics 89:583-590.

Peyruchaud O, Nurden A and Borre F (1995) Bilateral linkage between a new deletion polymorphism in intron 21 of the GP IIb gene and the HPA-3b (Bakb) determinant. Br J Haematol 91:747-51.

Piazza A, Capello EN, Olivetti E and Rendine S (1988) A genetic history of Italy. Ann Hum Genet 52:203-213.

Reiner AP, Siscovick DS and Rosendaal FR (2001) Haemostatic risk factor and arterial thrombotic disease. Thromb Haemost 85:584-595. 
Rickards O, Martinez -Labarga C, Scano G, De Stefano GF, Biondi G, Pacaci M and Walter H (1998) Genetic history of the population of Sicily. Hum Biol 7:669-714.

Ruan C, Gu J, Wang X, Chu X and Pan J (1993) Application of GPIIIa gene Taq I polymorphism to determination of carrier status in Glanzmann's thrombasthenia families of Chinese origin. Thromb Haemost 69:64-69.

Saitou N and Nei M (1987) The neighbor-joining method: a new method for reconstructing phylogenetic trees. Mol Biol Evol 4:406-25.

Schmidt H, Schmidt R, Niederkorn K, Horner S, Becsagh P, Reinhart B, Schumacher M, Weinrauch V and Kostner GM (1998) Beta-fibrinogen gene polymorphism $(\mathrm{C} 148 \rightarrow \mathrm{T})$ is associated with carotid atherosclerosis: Results of the Austrian Stroke Prevention Study. Arterioscler Thromb Vasc Biol 18(3):487-92

Schneider S, Roessli D and Excoffier L (2000) Arlequin: A software for population genetics data analysis. Ver 2.000. Genetics and Biometry Lab, Dept. of Anthropology, University of Geneva.

Steeds R, Adams M, Smith P, Channer K and Samani NJ (1998) Distribution of tissue plasminogen activator insertion/deletion polymorphism in myocardial infarction and control subjects. Thromb Haemost 79:980-984.

Thomas A, Lamlum H, Humphries S and Green F (1994) Linkage disequilibrium across the fibrinogen locus as shown by five genetic polymorphisms, G/A-455 (HaeIII), C/T-148 (HindIII/AluI), T/G+1689 (AvaII), and BclI (betafibrinogen) and TaqI (alpha-fibrinogen), and their detection by PCR. Hum Mutat 3:79-81.

Tishkoff SA, Pakstis AJ, Stoneking M, Kidd JR, Destro-Bisol G, Sanjantila A, Lu RB, Deinard AS, Sirugo G, Jenkins T, Kidd KK and Clark AG (2000) Short tandem-repeat polymorphism/Alu haplotype variation at the PLAT locus: Implications for modern human origins. Am J Hum Genet 67:901-925.

Tishkoff SA, Ruano G, Kidd JR and Kidd KK (1996) Distribution and frequency of a polymorphic Alu insertion at the plasminogen activator locus in humans. Hum Genet 97:759-764.

Tunstall-Pedoe H, Kuulasmaa K, Amouyel P, Arveiler D, Rajakangas AM and Pajak A (1994) Myocardial infarction and coronary deaths in the World Health Organization MONICA Project. Circulation 90:583-602. van der Bom JG, Knijff P de, Haverkate F, Bots ML, Meijer P, de Jong PT, Hofman A, Kluft C and Grobbee DE (1997) Tissue type plasminogen activator and risk of myocardial infarction. The Rotterdam Study. Circulation 95:2623-2627.

Varesi L, Memmi M, Cristofari MC, Mameli GE, Calò CM and Vona G (2000) Mitochondrial control-region sequence variation in the Corsican population, France. Am J Hum Biol 12:339-351.

Vona G (1997) The peopling of Sardinia (Italy): History and effects. Int J Anthropol 12:71-87.

Vona G, Ghiani ME, Calò CM, Vacca L, Memmi M and Varesi L (2001) Mitochondrial DNA sequence analysis in Sicily. Am J Hum Biol 13:576-589.

Vona G, Memmì M, Calò CM, Latini V, Vacca L, Succa V, Ghiani ME, Moral P and Varesi L (2002) Genetic structure of the Corsican population (France): A review. Recent Res Devel Human Genet 1:147-164.

Vona G, Moral P, Memmì M, Ghiani ME and Varesi L (2003) Genetic structure and Affinities of the Corsican population (France): Classical genetic marker analysis. Am J Hum Biol 15:151-163.

Weir BS (1991) Genetic data analysis. Sinauer Publ, Sunderland, MA, USA.

Weiss EJ, Bray PF, Tayback M, Schulman SP, Kickler TS, Becker LC, Weiss JL, Gerstenblith G and Goldschmidt-Clermont PJ (1996) A polymorphism of a platelet glycoprotein receptor as an inherited risk factor for coronary thrombosis. N Engl J Med 334(17):1090-1094.

Zei G, Barbujiani G, Lisa A, Fiorani O, Menozzi P, Siri E and Cavalli-Sforza LL (1993) Barriers to gene flow estimated by surnames distribution in Italy. Ann Hum Genet 57:123-140.

Zimrin AB, Gidwitz S, Lord S, Schwartz E, Bennett JS, White II GC and Poncz M (1990) The genomic organization of platelet glycoprotein IIIa. J Biol Chem 265:8590-8595.

Zito F, Di Castelnuovo A, Amore C, D'Orazio A, Donati MB and Iacoviello L (1997) BclI polymorphism in the fibrinogen $\beta$-chain gene is associated with the risk of familial myocardial infarction by increasing plasma fibrinogen levels. Arterioscler Thromb Vasc Biol 17:3489-3494.

Zito F, Di Castelnuovo A, D’Orazio A, Negrini R, De Lucia D, Donati MB and Iacoviello L (1999) Helicobacter pylori infection and the risk of myocardial infarction: role of fibrinogen and its genetic control. Thromb Haemost 82:14-8.

Editor Associado: Francisco Mauro Salzano 